\title{
РЕЗУЛЬТАТЫ ГРАВИМЕТРИЧЕСКИХ И МАГНИТОМЕТРИЧЕСКИХ ИССЛЕДОВАНИЙ ПРИРОДЫ ПУЛЫТЬИНСКОЙ СЕЙСМИЧЕСКОЙ АНОМАЛИИ ЗАПАДНОЙ СИБИРИ
}

\author{
Г. П. Щербинина, Г. В. Простолупов \\ Горный институт Уральского отделения РАН, г. Пермь \\ Поступила в редакцию 9 июля 2018 г.
}

\begin{abstract}
Аннотация: в статье приведены результаты гравиметрических и магнитометрических исследований Пультьинской сейсмической кольцевой аномалии, выявленной в 2007 г севернее г. Тюмени. Детальные измерения гравитационного и магнитного полей проведены по двум ортогонально пересекающимся профилям с точкой пересечения в центре кольчевой структуры. В пределах сейсмической аномалии гравитационное поле в корне отличается от окружающих пространств. Наблюдается высокочастотная смена положительных и отрицательных кольцевых аномалий. В магнитном поле Пультььиской сейсмической аномалии соответствует положительная аномалия АТа амплитудой 225 нТл. Комплексный анализ морфологии потенциальных полей, сейсморазведочных и геохимических материалов и других видов исследований позволяет говорить об ударной, в результате падения метеорита, природе сейсмической аномалии.
\end{abstract}

Ключевые слова: кольцевая сейсмическая аномалия, гравитационное поле, магнитное поле, природа геофизической аномалии.

\section{RESULTS OF GRAVIMETRIC AND MAGNETOMETRIC RESEARCH OF NATURE OF PULYTINSKOYE SEISMIC ANOMALY WESTERN SIBERIA}

\begin{abstract}
Pulytinskoye seismic ring anomaly revealed in 2007 to the north of Tyumen. Detailed measurements of the gravitational and magnetic fields are carried out along two orthogonally intersecting profiles crossing in the center of the ring structure. Within the seismic anomaly, the gravitational field is extremely different from the outer surrounding spaces. There is a high-frequency change of positive and negative annular anomalies. In a magnetic field Pulytinskoye seismic anomaly corresponds to a positive anomaly with an amplitude of 225 nT. Complex analysis of the morphology of potential fields, seismic and geochemical materials and other types of surveys allows us to speak about the impact nature of the seismic anomaly, as a result of the meteoric fall.
\end{abstract}

Keywords: ring seismic anomaly, gravitational field, magnetic field, nature of geophysical anomaly.

\section{Введение}

В сибирском регионе, в том числе на ЗападноСибирской плите сейсморазведочными работами обнаруживаются различного рода нестандартные возмущения волновой картины, о происхождении которых нет единодушия среди геологов. Одни считают их импактными структурами, образовавшимися в результате падения на Землю крупных метеоритов, другие считают их эндогенными образованиями - взрывными структурами или результатом дегазации планеты.

В 2007 г. сейсмическими работами по методике 3D (ОАО «Хантымансийскгеофизика») в 300 км севернее г. Тюмени обнаружена аномалия сейсмического поля - Пулытинская, природа которой дискутируется в печати, в том числе сторонниками проявления современной геодинамической активности недр $[1,2]$.

В данной статье на основе дополнительных иссле- дований - гравиразведочных работ высокой точности - высказывается иной взгляд на природу выявленной сейсмической аномалии.

Аномалия Пулытьинская представляет конусообразное тело нарушения волновой картины (рис. 1), наблюдаемое в пределах осадочного чехла. Диаметр конусообразной структуры в верхней части разреза составляет около 4 км. На временных срезах наблюдается концентрическая область правильного строения (рис. 2). Сейсморазведкой закартирована внутренняя структура объекта. В осевой части трубки зафиксирована хаотическая картина осей синфазности с элементами положительной структуры, степень нарушенности отражений увеличивается вверх. Подобное строение волнового поля наблюдается в юрской осадочной толще ударного кратера Mjølnir в Норвежском море [3]. 


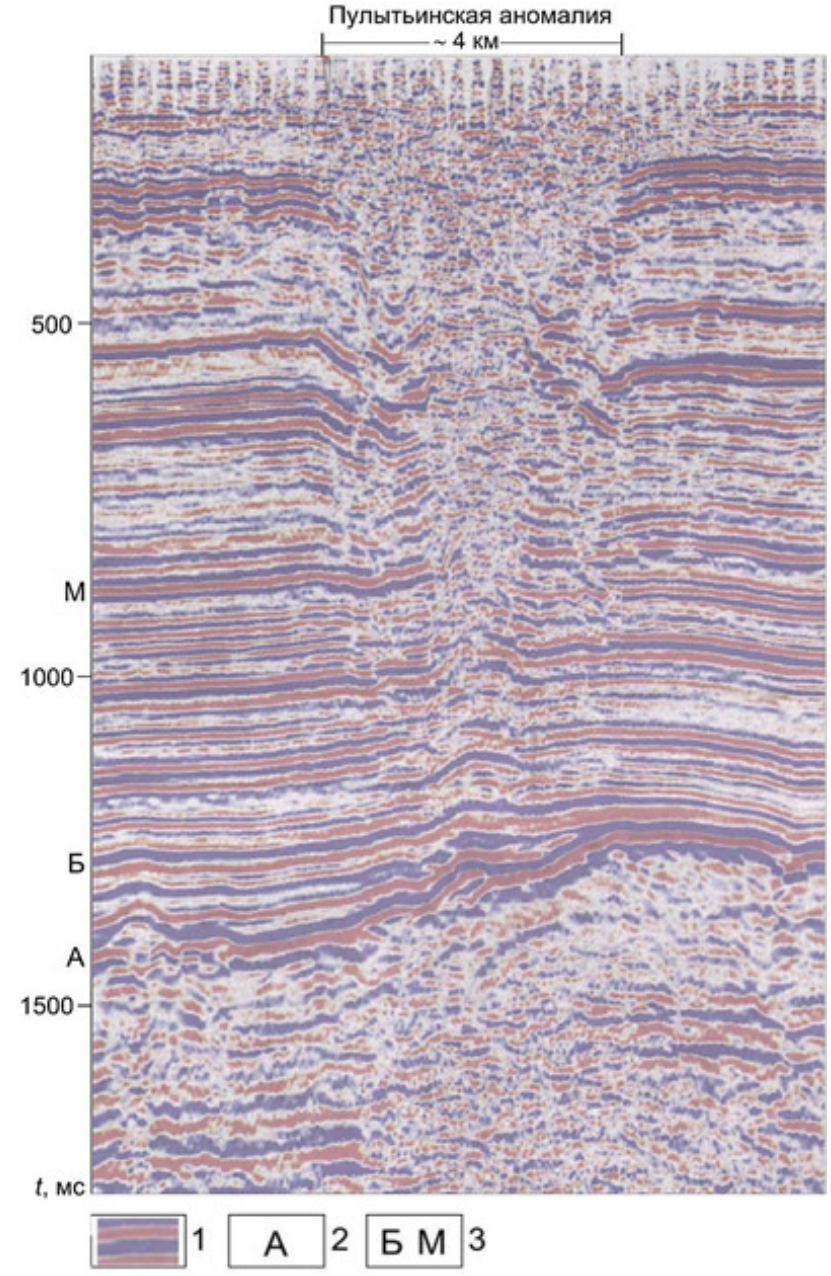

Puc. 1. Пулытьинская сейсмическая аномалия на временном разрезе: 1 - отраженные волны: розовый цвет - положительные фазы, синий - отрицательные фазы; 2 - граница осадочного чехла и фундамента; 3 - опорные отражающие границы в осадочном чехле.
В настоящее время Пулытьинская аномалия сейсмического поля входит в состав лицензионного участка, где ведется детальное изучение геологического строения с целью выявления ловушек углеводородов в мезозойско-кайнозойском осадочном чехле. Примеры нефтегазосности кольцевых структур многочисленны $[4,5]$. Пулытьинская кольцевая аномалия также может рассматриваться в качестве объекта, перспективного на выявление залежей УВ.

\section{Геологическая характеристика}

Территория, где обнаружен Пулытьинский сейсмический объект, имеет характерное для ЗападноСибирского региона геологическое строение. Разрез состоит из осадочного чехла и палеозойского фундамента. Глубина залегания поверхности фундамента 1,5-2 км. Осадочный чехол сложен песчано-алевритовыми и глинистыми отложениями мезозойкайнозойского возраста. Залегание слоев субгоризонтальное. Мезозой-кайнозойская толща Западной Сибири отличается низкими скоростями распространения сейсмических волн (около 2,7-3,0 км/с), малой

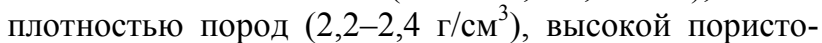
стью, т.е. это «молодые», малоуплотненные и слабо консолидированные породы. Это определяет их относительно низкие прочностные свойства и неупругое поведение при механических воздействиях.

Территория обнаружения Пулытьинской аномалии характеризуется выровненным рельефом земной поверхности с отметками $+81-+96$ м. Сейсмическому объекту соответствует незамкнутое кольцо пониженных значений рельефа с заболоченностью. Внешний диаметр этого кольца около 2,5 км. Таким образом, можно констатировать, что сейсмический объект проявляется в современном рельефе земной поверхности. В плиоценовое время на данной территории происхо-

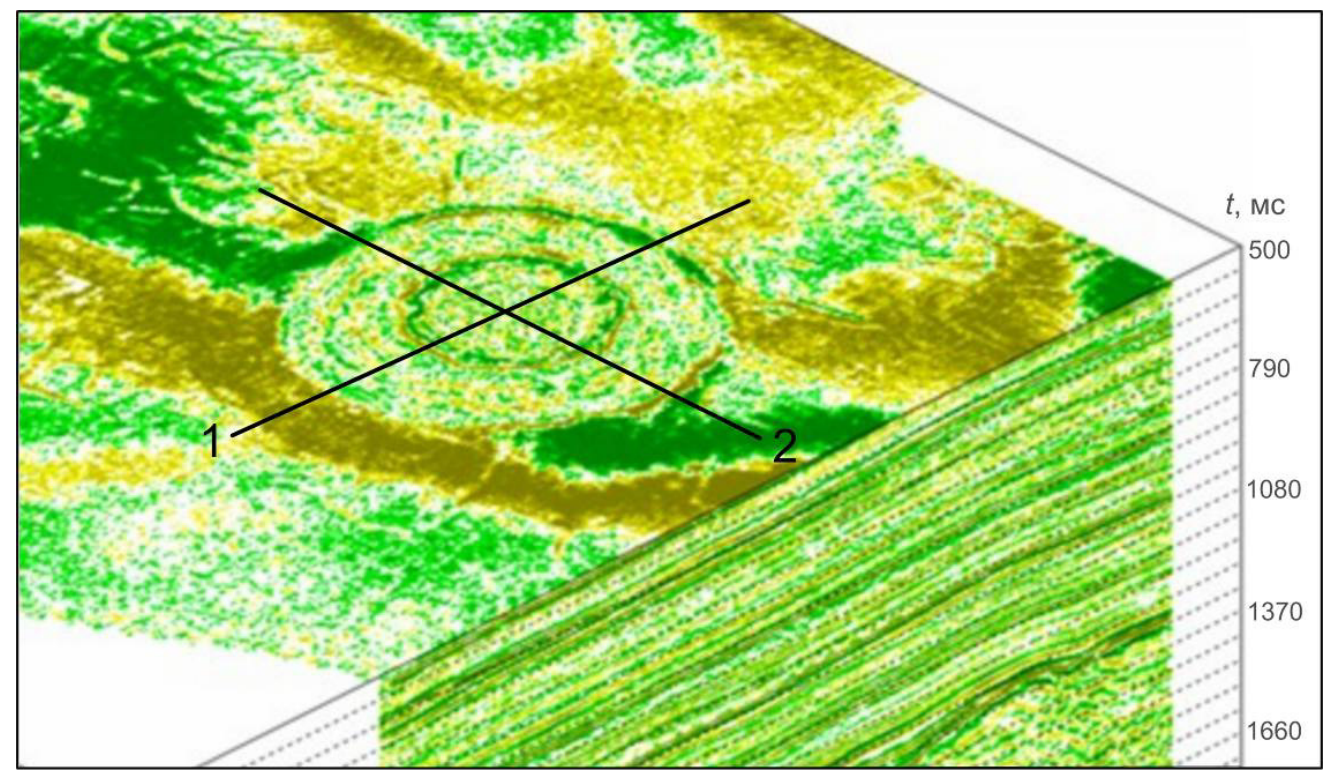

Puc. 2. Срез 3D-куба на времени 500 миллисекунд и схема расположения профилей гравиметрической и магнитометрической съемок (желтым цветом обозначены положительные фазы отраженной волны, зеленым - отрицательные). 
дило две трансгрессии моря, которые перекрывали осадками неровности предшествующего рельефа, выравнивая земную поверхность. Поскольку изучаемый объект проявляется в рельефе в настоящее время, то можно сделать некоторое заключение об его возрасте. Скорее всего, он сформировался в послеплиоценовое время и имеет возраст не более двух млн. лет, т.е. относительно молодой.

Кольцевая структура Пулытьинского объекта проявляется и на космических снимках.

Природа Пулытьинской сейсмической аномалии не очевидна и поэтому вызывает интерес. С целью выяснения ее происхождения был проведен комплексный анализ результатов различных видов исследований.

Геохимическое поле данной площади [6] характеризуется многокомпонентностью, устойчивыми ассоциациями элементов и высокой контрастностью. Содержание метана в районе осевой части трубки превышает фоновые значения в 70 раз, гелия - в 40 раз, водорода - в 39 раз [1, 7]. Отмечено наличие более тяжелых, чем метан фракций углеводородов. В пределах объекта обнаружены редкие и редкоземельные элементы: ртуть, ниобий, кобальт, никель, висмут, иттрий, иттербий, медь, цинк и др. Процентное содержание их в центральной части объекта превышает фоновое в 2-5 раз. Наличие высокого содержания гелия, ртути и других микроэлементов указывает, по мнению автора работы [7], на большую глубинность их очагов. В контрастных аномалиях гелия, водорода, метана, углекислого газа, этана, пропана проявляется кольцевая структура объекта, ароматические и высокомолекулярные УВ образуют прерывистые аномалии [1].

Таким образом, результаты геохимических исследований говорят о том, что глубокие недра в районе Пулытьинской аномалии активны в настоящее время. Современная геодинамическая активность в виде кольцевых выходов на земную поверхность глубинных флюидов свидетельствует о наличии в пределах объекта кольцевых проницаемых зон, по которым в настоящее время происходит вертикальная миграция газов.

В то же время отмечается повышенное содержание элементов группы железа $(\mathrm{Ni}, \mathrm{Co}, \mathrm{Cu})$, свойственных метеоритам, особенно никеля, который является геохимическим индикатором отличий метеоритного вещества [8].

В результате дешифрирования и количественной интерпретации космических видеотепловизионных данных методом дистанционной терморазведки выявлено, что кольцевая структура объекта прослежена в современном геотермическом пространстве на глубину до 600 м [1].

\section{Измерение потенциальных полей}

В 2008 году на сейсмической кольцевой структуре геофизической экспедицией Горного института Уральского отделения РАН (г. Пермь) были проведены детальные гравиметрические и магнитометриче- ские исследования по двум пересекающимся профилям. Длина каждого профиля 6 км. Пересечение профилей приурочено к центру кольцевой структуры (рис. 2). Расстояние между пунктами измерения силы тяжести на профилях 50 м, между пунктами измерения напряженности магнитного поля - 25 м. Магнитная съемка проводилась квантовыми магнитометрами MMП-203 и MMPOS-1. Гравиметрические наблюдения выполнялись высокоточными гравиметрами AUTOGRAV CG-5 фирмы SCINTREX (Канада). Применялась однократная методика съемки. Гравиметрическая съемка проведена с высокой точностью. Среднеквадратическая погрешность определения аномалии Буге (с учетом погрешности наблюденных значений силы тяжести, определения высот и плановых координат пунктов наблюдений) составила $\pm 0,013$ мГал. Точность определения магнитного поля \pm 5 нТл.

Результаты измерений потенциальных полей приведены на рис. 3. На графиках $\Delta \mathrm{g}$ Буге наблюдается ритмичная высокочастотная картина локальных аномалий. На каждом из графиков отмечается по шесть отрицательных и по пять положительных аномалий. К центру кольцевой структуры приурочена локальная положительная аномалия А, наиболее интенсивная и широкая. Ее амплитуда 2,0-2,2 мГал относительно соседних минимумов и 1,0-1,3 мГал относительно фонового поля, ширина 1,5 км. Изменение поля на расстоянии 750 м на величину 2 мГал является значительным и соответствует высокому градиенту изменения плотности пород по латерали. От центра кольцевой структуры к периферии ширина и амплитуда локальных аномалий закономерно уменьшаются до 0,5 км и 0,2 мГал соответственно. Длина области высокоградиентного изменения поля $\Delta \mathrm{g}$ на профилях составляет 5,2 и 5,6 км. На концах графиков $\Delta \mathrm{g}$ наблюдаются выровненные участки длиной 0,2-0,5 км, которые характеризуют поле ненарушенных толщ за пределами аномальной зоны. По локальным максимумам и минимумам гравитационного поля отчетливо видно, что в пределах аномального участка наблюдается чередование уплотненных и разуплотненных пород. Степень уплотнения и разуплотнения уменьшается к периферии аномальной зоны.

Сопоставление графиков поля $\Delta \mathrm{g}$, измеренного на широтном и меридиональном профилях, показывает практически их полное подобие (рис. 3). Причем видно, что общий фон гравитационного поля увеличивается в сторону северного и восточного концов профилей, т.е. на северо-восток. Наблюдается корреляция фона с поверхностью доюрского основания на данном участке.

Таким образом, на графиках поля $\Delta \mathrm{g}$ выделяется центральная высокоградиентная область и слабоградиентная периферическая часть. Наложение гравитационного поля на космический снимок показывает его хорошее отражение в рисунке снимка. Совпадение в плане концентрической сейсмической структуры, кольцевой картины космического снимка с областью высокочастотных кольцевых аномалий гравитационного поля позволяет считать, что гравитационное по- 
ле на данном объекте также имеет концентрическое строение. Это позволяет соединить точки графиков силы тяжести окружностями максимумов и окружностями минимумов (рис. 4).
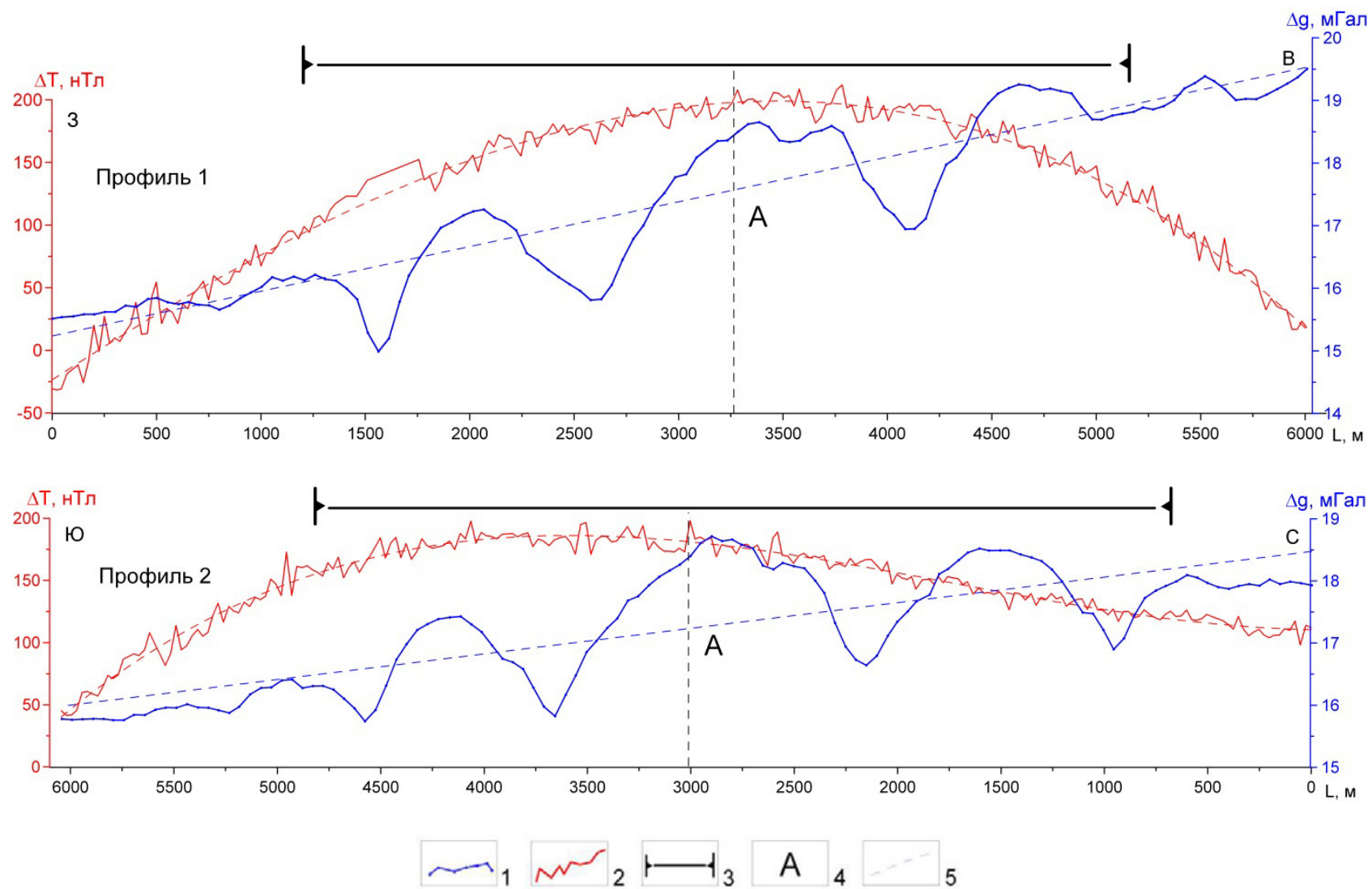

Puc. 3. Графики гравитационного и магнитного полей: 1 - график гравитационного поля $\Delta \mathrm{g}$ Буге; 2 - график магнитного поля $\Delta \mathrm{T} ; 3$ - высокоградиентная область поля $\Delta \mathrm{g}$ Буге; 4 - центральная положительная аномалия гравитационного поля; 5 - линейный фон гравитационного поля.

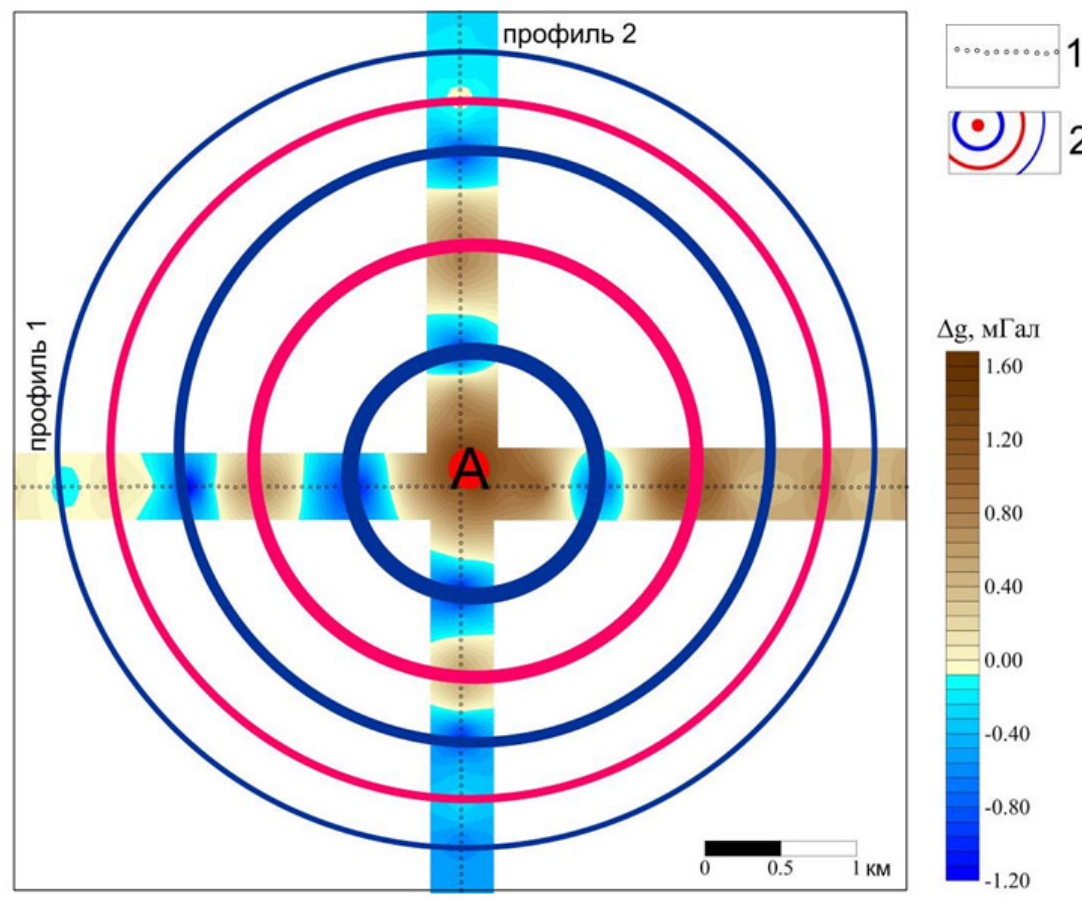

Puc. 4. Результаты гравиметрических измерений: 1 - гравиметрические профили, 2 - экстремумы положительных и отрицательных аномалий (кольца уплотненных и разуплотненных пород). 
Подобная картина гравитационного поля, состоящего из колец положительного и отрицательного знака, наблюдается и на других объектах. Например, гравитационное поле Попигайского метеоритного кратера (Сибирская платформа) [9], Курского (Воронежский кристаллический массив) [10, 13], кратера Mjølnir (Норвегия) [3, 11]. Окружности минимумов указывают на положение наиболее разуплотненных, следовательно, наиболее проницаемых круговых зон, окружности максимумов - соответственно, уплотненных.

Таким образом, гравитационное поле отражает концентрически правильную плотностную картину строения Пулытьинской сейсмической аномалии.

Глубина, до которой распространена система разноплотностных колец, определяется на вертикальных сечениях трехмерных диаграмм гравитационного поля, построенных в программе VECTOR [12] (рис. 5). Судя по шкале эффективных глубин на рисунке, область кольцевого строения в центральной части изучаемого объекта достигает глубины 600 м, на периферии глубина уменьшается до 350 м. Как уже было отмечено, в тепловом поле кольцевая структура объекта прослежена также до глубины 600 м.

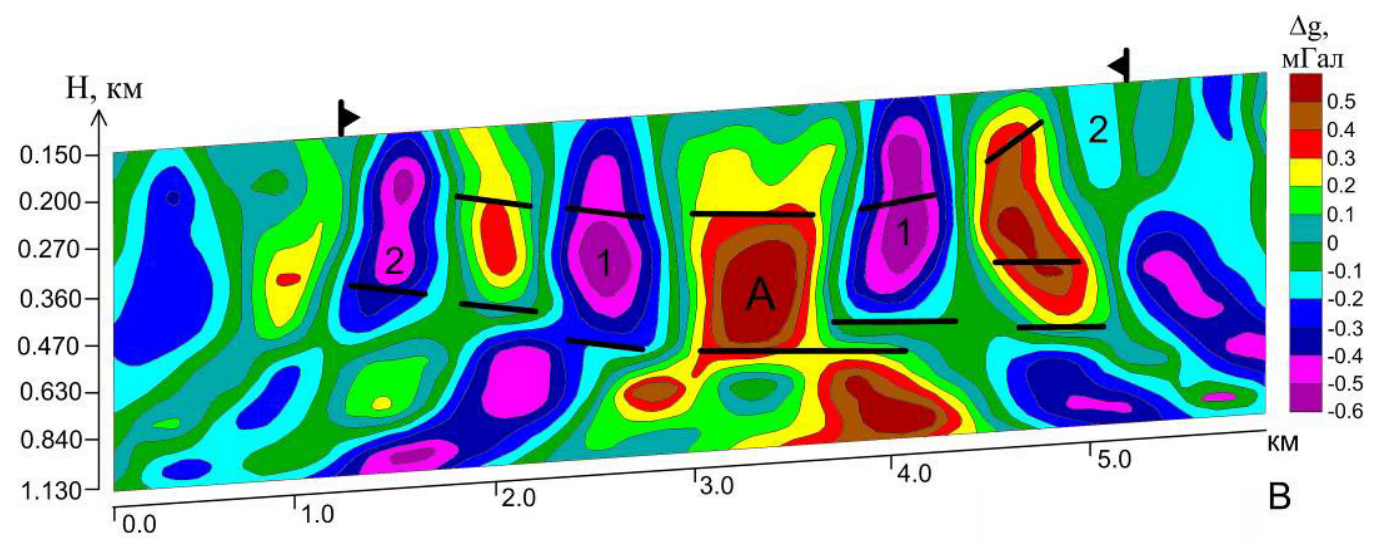

Профиль 13

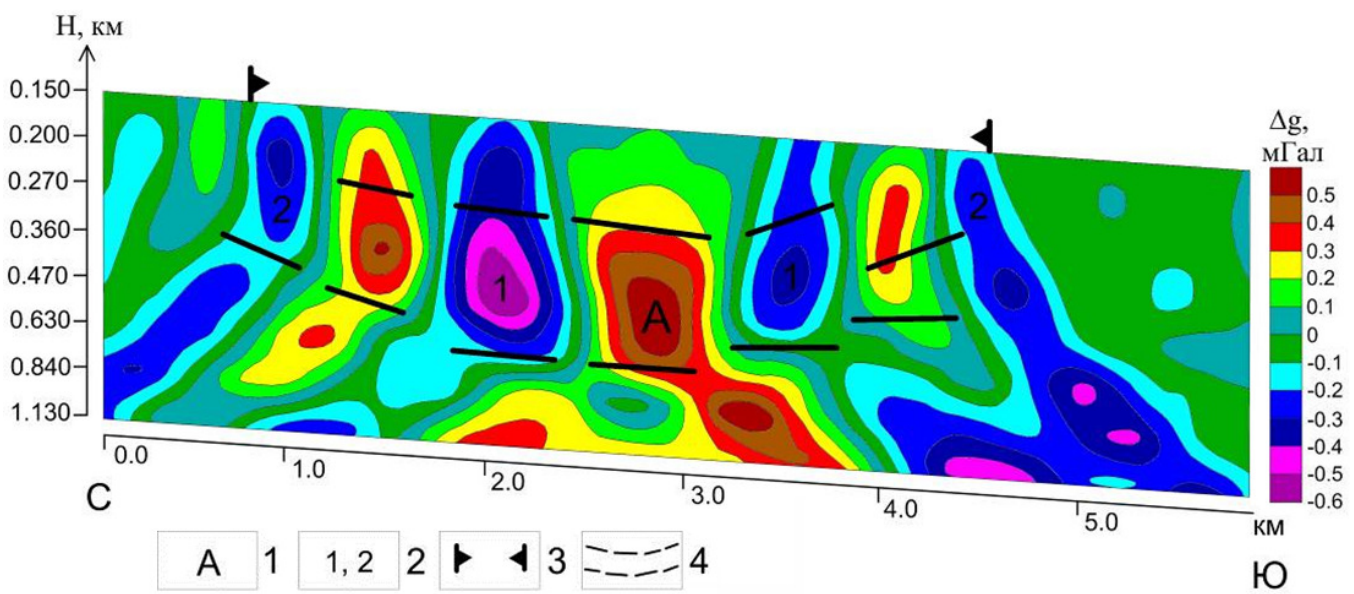

Профиль 2

Puc. 5. Вертикальные сечения трехмерных трансформант гравитационного поля по профилям: 1 - центральная положительная аномалия; 2 - отрицательные аномалии первого и второго колец; 3 - высокоградиентная область; 4 - слой интенсивной изменчивости плотности.

На этом уровне глубин на рис. 5 четко выделяется центральная положительная аномалия А, отображающая наличие плотного объекта в центральной части Пулытьинской аномалии, а также отрицательные и положительные аномалии, отражающие кольца контрастной плотности.

Наблюдаемый на трехмерных диаграммах гравитационного поля высокоградиентный слой кольцевого распределения плотности имеет по глубине блюдцеобразную форму с погруженной центральной частью. Это напоминает форму области измененных пород, наблюдаемую в кратерах других ударных структур.
Несколько конкретных примеров. Курский метеоритный кратер (Воронежский кристаллический массив) [10] был выявлен гравиметрический съемкой и изучен несколькими скважинами. Породы среднего, верхнего девона и карбона выполняют локальную впадину в кристаллическом фундаменте. Глубина впадины при диаметре кратера 15 км составляет 200250 м. В центре впадина осложнена поднятием кристаллических пород.

Результаты моделирования ударной структуры Mjølnir [3] показали сложное строение вогнутой зоны удара, с наличием центрального поднятия, с зонами 
различной степени разрушенности и пород.

Кунгуртауская структрура (Тургайский прогиб) [13] имеет диаметр около 1 км. В гравитационном поле зафиксирована идеально округлая отрицательная аномалия силы тяжести интенсивностью 5,5 мГал. В центре структуры пробурена скважина, вскрывшая на глубине около 200 м под рыхлыми отложениями породы скального фундамента.

Модельный подбор плотности на Пулытьинской аномалии по гравитационному полю в пределах эффективных глубин от 300 до 400 м, где наблюдаются чередующиеся аномалии высокоградиентного слоя, показал следующее. Разница подобранной плотности пород в плотных и разуплотненных кольцах составляет $0,4-0,5 \Gamma / \mathrm{cm}^{3}$. Если плотность пород за пределами изучаемого объекта равна $2,30 \mathrm{r} / \mathrm{cm}^{3}$, то плотность пород в пределах кольцевой структуры может изменяться от $2,05 \mathrm{r} / \mathrm{cm}^{3}$ в разуплотненных кольцах до 2,55 $\Gamma / \mathrm{cm}^{3}$ в уплотненных кольцах.

Ниже зоны кольцевого строения картина аномалий на вертикальных сечениях трехмерных трансформант менее градиентная.

Таким образом, вертикальные сечения трехмерных трансформант гравитационного поля показывают наличие латеральной зональности плотностного строения в верхней части Пулытьинского объекта, а также неоднородность по вертикали.

Графики напряженности магнитного поля $\Delta \mathrm{T}$ приведены на рис. 3. Они представляют плавные кривые с максимальными значениями, приуроченными к центральной части изучаемого объекта на профиле 1 (3В), и смещением на юг на профиле 2 (Ю-С). Амплитуды аномалий в пределах профилей составляют 225 нТл на широтном профиле и 125 нТл на меридиональном. Форма графиков говорит о том, что в пределах профилей зафиксирована только центральная часть обширной положительной аномалии.

При увязке результатов наблюдений магнитного поля, проведенных на разных профилях, в точке пересечения профилей принят единый уровень поля. В результате была получена картина поля $\Delta \mathrm{T}$ в плане. Наблюдается аномалия эллиптической формы с максимумом, расположенным вблизи центра кольцевой структуры. Ось аномалии ориентирована в направлении С-СВ - Ю-ЮЗ.

\section{Интерпретация природы сейсмической аномалии}

Обобщение и увязка данных различных видов исследований Пулытьинского сейсмического объекта, характеризующих его проявление в разных физических и геохимических полях, позволяет сделать следующие выводы.

Пулытьинский объект, выраженный в сейсмическом поле в виде конусообразного тела с зональноконцентрическим строением волновой картины, является, скорее всего, ударной структурой метеоритного происхождения. Об том, в частности, свидетельствует строго правильное концентрически зональное строение сейсмической и плотностной картин верхней ча- сти объекта. При эндогенном генезисе (вулканические взрывы, эксплозивная эндогенная дегазация, электроразрядные взрывы [14], геосолитонные трубки [1, 2, 7]) гравитационная картина не была бы такой правильно концентрической, состоящей из нескольких разноплотностных колец, «вложенных» одно в другое. В случае эндогенного генезиса плотностные кольца, если бы они сформировались, не имели бы такую выдержанную по кругу толщину и резкую (14-20\%) контрастность изменения плотности пород.

Обзор литературы по метеоритным кратерам $[9,15$ и др.] показывает, что в гравитационном поле ударные структуры могут проявляться по-разному. Принято считать, что метеоритные кратеры в гравитационном поле проявляются отрицательными аномалиями. В работе [15], напротив, констатируется, что «..поле силы тяжести над астроблемами не имеет каких-либо специфических признаков..».

Особенностью же гравитационного поля Пулытьинского объекта является наличие центральной крупной положительной аномалии. Центральное уплотнение А (рис. 5) можно интерпретировать как область ударного сжатия слабых малоуплотненных глинистопесчаных пород осадочного чехла при ударе средней силы. Представляется, что ударная сила здесь была намного меньше, чем в хорошо изученных ПучежКатунской [16-21] и Попигайской $[9,22]$ астроблемах, которые имеют диаметр 80-100 км. Породы мишени в этих астроблемах претерпели глубокие изменения с раздроблением пород и формированием брекчий.

В данном же случае можно предположить, что относительно слабые по механическим свойствам породы осадочного чехла Западно-Сибирского региона и незначительной силы удар обусловили своеобразие деформирования пород мишени, заключающееся в формировании волн уплотнения и разуплотнения. Кроме того, концентрическое плотностное строение, наблюдаемое только в верхней части, также показывает, что источник формирования Пулытьинского объекта находился наверху, а не на глубине.

Наличие газовых и геохимических аномалий в настоящее время, а также кольцевую структуру геотермического пространства можно объяснить молодым возрастом Пулытьинского импакта, когда процессы в недрах, вызванные ударным воздействием, еще продолжаются. Источником геохимических элементов кроме космического тела могут быть как глубокие земные недра (мантия), возбужденные ударом, так и другие толщи, в том числе осадочный чехол. Породы ударной мишени, при шоковой декомпрессии после удара выделяют различные элементы [20], которые, при достаточно небольшой давности удара на изучаемом объекте, фиксируются на земной поверхности. Контрастность геохимических аномалий [1] объясняется, вероятно, резкой изменчивостью проницаемости в разноплотностных кольцах.

В магнитном поле импактные структуры проявляются также по-разному. На морфологию поля сильное влияние оказывает гетерогенность мишени. Над Пу- 
чеж-Катунским кратером (район Нижнего Новгорода) кольцевая структура проявляется в деформировании магнитных аномалий естественного поля [23].

Это объясняется генерацией мелких кристаллов ферримагнетика, выделенных из железосодержащих минералов осадочного чехла, при соударении массивного тела с поверхностью Земли. Наличие такой генерации мелких магнетитовых зерен обнаружено в центральной части Пучеж-Катунской астроблемы. По данным [21] в скважине, пробуренной в пределах данной астроблемы, продукты термального метаморфизма характеризуются аномальной магнитной восприимчивостью и высокой остаточной намагниченностью.

Рагозинской астроблеме (Средний Урал) в магнитном поле соответствует область относительно спокойных, и большей частью, отрицательных значений $\Delta \mathrm{T}_{\mathrm{a}}$ на фоне субмеридиональных знакопеременных аномалий [15]. Если импактная структура возникла в однородно намагниченных породах, то она может быть совсем не выражена в магнитном поле, например астроблема Шийли [15].

Над изучаемой Пулытьинской геофизической аномалией магнитное поле представляет положительную эллипсовидную в плане аномалию с максимумом, расположенным вблизи центра сейсмической и гравитационной круговых аномалий. Такая картина магнитного поля на ударных объектах в литературе не встречена. Для объяснения данной измеренной аномалии $\Delta \mathrm{T}$ требуются дополнительные исследования.

\section{Выводы}

Построенная по материалам высокоточной гравиметрической съемки объемная плотностная модель верхней части геологического разреза в пределах Пулытьинской сейсмической аномалии показала концентрически правильную картину плотностного строения. До глубины 350 м на периферии объекта и до 600 м в центральной части породный массив представляет упорядоченную пространственную структуру, состоящую из нескольких колец уплотненных и разуплотненных пород. Ширина колец контрастной плотности закономерно уменьшается к периферии сейсмической круговой аномалии от 800 м до 500 м. Разница плотности пород в плотных и разуплотненных кольцах, согласно решению обратной задачи гравиметрии, составляет от 0,4 до $0,5 \mathrm{r} / \mathrm{cm}^{3}$. В центре кольцевой структуры наблюдается наиболее уплотненный блок диаметром около $800 \mathrm{~m}$.

Наличием кольцевой зональности плотности пород (соответственно и проницаемости) верхней части разреза, очевидно, объясняется кольцевая форма высококонтрастных аномалий наблюдаемых здесь геохимических полей, показателей дистанционной терморазведки.

Комплексный анализ результатов различных видов исследований позволяет трактовать Пулытьинскую сейсмическую аномалию как результат падения на поверхность Земли космического тела, т.е. как ударную структуру, деформировавшую осадочный чехол.
Морфология магнитного поля на данном локальном участке, зарегистрированная с высокой точностью, пока не находит объяснений. Для выяснения ее природы и соотношения с кольцевой структурой требуются дополнительные исследования.

Пулытьинская кольцевая структура, выявленная сейсморазведкой на перспективной территории в нефтедобывающем регионе, отмечается контрастными аномалиями углеводородных газов, отражающими скопление УВ. Поэтому данную структуру в целом, очевидно, можно рассматривать как высокоперспективную для поисков залежей УВ-сырья. Аккумуляция УВ в деформированных толщах пород может иметь сложный характер и привести к формированию залежей необычной геометрии.

\section{ЛИТЕРАТУРА}

1. Бембель, С. Р. Особенности проявления современной локальной геодинамики в западной части ХМАО-Югра, их связь с очагами нефтегазонакопления / С. Р. Бембель // Геология нефти и газа. - 2010. - №4. - С. 8-12.

2. Бембель, Р. М. Геосолитонная природа субвертикальных зон деструкции / Р. М. Бембель, С. Р. Бембель, В. М. Мегеря // Геофизика. - 2001. - Спец. выпуск. - С. 36-50.

3. Werner, S. C. Downsizing the Mjølnir impact structure, Barents Sea, Norway / S. C. Werner, T. H. Torsvik // Tectonophysics. $-2010 .-$ V. 483. - P. 191-202.

4. Смирнова, М. Н. Нефтегазоносные кольцевые структуры и научно-методические аспекты их изучения / М.Н. Смирнова // Геология нефти и газа. - 1997. - № 9. - С. 1-6.

5. Пиковский, Ю. И. Блоковая структура и нефтегазоносность импактного кратера Сильян / Ю. И. Пиковский, М. П. Гласко, В. Г. Кучеров // Геология и геофизика. -2017 . - №2. - C. 243-249.

6. Мясников, И. Ф. Отчет о результатах комплексных газолитохимических исследований на Пулытьинском объекте / И. Ф. Мясников, В. В. Югин. - Черноголовка: Изд-во ООО «АНЧАР-Геокомплекс», 2008. - 55 с.

7. Мегеря, В. М. Поиск и разведка залежей углеводородов, контролируемых геосолитонной дегазацией Земли: монография / В. М. Мегеря. - М.: Локус Станди, 2009. - 256 с.

8. Антипин, В. С. Происхождение Патомского кратера (Восточная Сибирь) по геолого-геохимическим данным / В. С. Антипин, А. М. Федоров // ДАН. - 2008. - Т. 423 - №5. - С. 361-366.

9. Стогний, В. В. Глубинное строение Попигайской кольцевой структуры по результатам анализа геофизических полей / В. В. Стогний, Г. А. Стогний // Отечественная геология. 2007. - №5. - C. 111-113.

10. Орлов, Р. А. Опыт использования микросейсмического шума для решения геологических задач в условиях платформы (на примере Воронежского кристаллического массива / Р. А. Орлов // Вестн. Воронеж. гос. ун-та. - Сер.: Геология. - 2011. - №1. - С. 184-192.

11. Integrated geophysical analysis supporting the impact origin of the Mjølnir structure, Barents Sea / F. Tsikalas [et al.] // Tectonophysics. - 1998. - V. 289. - P. 257-280.

12. Об интерпретации гравитационного и магнитного полей на основе трансформации горизонтальных градиентов в системе «VECTOR» / Г. В. Простолупов [и др.] // Физика Земли. - 2006. - №6. - С. 90-96.

13. Сахновский, М. Л. Прогнозирование не выходящего на поверхность оруденения при глубинном геологическом картировании и геологическом доизучении площадей / M. 
Л. Сахновский, П. А. Литвин, Б. М. Михайлов. - СПб.: Издво ВСЕГЕИ, 2003. -273 с.

14. Хазанович-Вульф, К. К. Космогенный и эндогенный факторы образования геологических взрывных структур / К. К. Хазанович-Вульф // ДАН. - 1994. - Т. 337. - №1. - С. 83-87.

15. Вишневский, С. А. Астроблемы / С. А. Вишневский. Новосибирск: ООО «Нонпараллель», 2007. - 288 с.

16. Галкина, О. Б. Магнитные исследования керна Воротиловской скважины к вопросу генезиса ВКС / О. Б. Галкина // Материалы Всероссийской научной конференции «Геология Русской плиты и сопредельных территорий на рубеже веков». - Саратов: Изд-во ГосУНЦ «Колледж», 2000. - С. 49-50. 17. Масайтис, В. Л. Глубокое бурение в Пучеж-Катункской импактной структуре / В. Л. Масайтис, Л. А. Певзнер. СПб.: Изд-во ВСЕГЕИ, 1999. - 392 с.

18. Мащак, Н. С. Основные черты морфологии и глубинного строения центрального поднятия Пучеж-Катункской астроблемы / Н. С. Мащак, В. Л. Масайтис // Материалы XXI всесоюзной метеоритной конференции. - М.: АН CCCP, 1990. - $140 \mathrm{c}$.

19. Певзнер, Л. А. Геология и алмазоносность ПучежКатункской импактной структуры / Л. А. Певзнер, А. К.

ФГБУН ПФИЦ УрО РАН филиал «Горный институт Уральского отделения Российской академии наук», г. Пермь

Щербинина Галина Прокопьевна, кандидат геологоминералогических наук, ведущчий научный сотрудник лаборатории геопотенциальных полей

E-mail: gena-prost@rambler.ru

Тел.: 8-952-318-67-12

Простолупов Геннадий Валерьевич, кандидат технических наук, старший научный сотрудник лаборатории геопотенциальных полей

E-mail: gena-prost@rambler.ru

Тел.: 8-902-475-66-98
Воронцов, О. Б. Галкина // Разведка и охрана недр. - 1999. № 11. - С. $12-18$.

20. Юшко, Н. А. Расплавные импактиты: геохимические признаки ударного метаморфизма (по данным глубокого бурения в Пучеж-Катункской астроблеме) / Н. А. Юшко, А. А. Кременецкий, А. К. Воронцов // Геохимия. - 1998. - №7. - С. 656-667.

21. Vorontsov, $A$. K. Characterization of impact rocks large ring structures / A. K. Vorontsov, L. A. Pevzner, V. L. Masaitis // The 31st International Geological Congress. - Rio de Janeiro: Geol. Surv. Braz, Aug 6-17, 2000. - P. 6405.

22. Векторное сканирование геопотенциальных полей Попигайской котловины / С. Г. Бычков [и др.] // Материалы 33-й сессии Междунар. семинара «Вопросы теории и практики геологической интерпретации гравитационных, магнитных и электрических полей». - Екатеринбург: Институт геофизики УрО РАН, 2006. - С. 69-73.

23. Дабижа, А. И. Геофизическая характеристика метеоритных кратеров. Метеоритные структуры на поверхности планет / А. И. Дабижа, В. В. Федынский. - М.: Наука, 1979. - С. 99-116.

Mining Institute of the Ural Branch Russian Academy of Sciences, Perm

Shcherbinina G.P., Candidate of Geological and Mineralogical Sciences, Leading Researcher of the laboratory of Geopotential Fields

E-mail: gena-prost@rambler.ru

Tel.: 8-952-318-67-12

Prostolupov G.V., Candidate of Technical Sciences, senior Researcher of the laboratory of Geopotential Fields

E-mail: gena-prost@rambler.ru

Tel.: 8-902-475-66-98 